\section{Kidney \\ Blood Pressure \\ Research}

Kidney Blood Press Res 2014;39:107-113

DOI: 10.1159/000355784
Published online: July 29, 2014

(C) 2014 S. Karger AG, Basel

www.karger.com/kbr

Accepted: April 11, 2014

1423-0143/14/0393-0107\$39.50/0

This is an Open Access article licensed under the terms of the Creative Commons AttributionNonCommercial 3.0 Unported license (CC BY-NC) (www.karger.com/OA-license), applicable to the online version of the article only. Distribution permitted for non-commercial purposes only.

Review

\title{
Nutrition and Physical Activity in CKD patients
}

\author{
Adamasco Cupisti Claudia D'Alessandro Giordano Fumagalli Valentina Vigo \\ Mario Meola Caterina Cianchi Maria F. Egidi
}

Department of Clinical and Experimental Medicine, University of Pisa; Nephrology, Transplantation and Dialysis Unit, AOUP, Pisa, Italy

\section{Key Words}

Chronic Kidney Disease $\cdot$ ESRD $•$ Nutrition $•$ Diet $•$ Dialysis $・$ Exercise $•$ Physical activity

\begin{abstract}
Chronic kidney disease (CKD) patients are at risk for protein-energy wasting, abnormal body composition and impaired physical capacity. These complications lead to increased risk of hospitalization, morbidity and mortality.

In CKD patient as well as in healthy people, there is a close association between nutrition and physical activity. Namely, inadequate nutrient (energy) intake impairs physical performance thus favoring a sedentary lifestyle: this further contributes to loss of muscle strength and mass, which limit the quality of life and rehabilitation of CKD patients. In CKD as well as in end-stage-renal-disease patients, regular physical activity coupled with adequate energy and protein intake counteracts protein-energy wasting and related comorbidity and mortality. In summary, exercise training can positively influence nutritional status and the perception of well-being of CKD patients and may facilitate the anabolic effects of nutritional interventions.
\end{abstract}

Copyright @ 2014 S. Karger AG, Basel

\section{Introduction}

Although the modern treatment of chronic kidney disease (CKD) is addressed to reduce progression of renal and cardiovascular damage, to prevent uremic complications and to improve survival, new challenges must be considered. In order to prevent disability, to improve quality of life and to maintain physical performance, it is important a proper nutritional approach and a regular physical activity.

Throughout the course of CKD, diet and exercise are widely recommended not only for improving the efficacy of drug and dialysis treatment, but also for offering specific benefits on physical performance, quality of life and health status perception. Nutrition and 


\section{Kidney Blood Pressure Research}

Cupisti et al.: Nutrition and Exercise in CKD

physical activity can also influence each other and closely interact both in healthy and in CKD population.

\section{Nutrition}

In the clinical care of renal patients, nutritional therapy is very important. Since the early stages of CKD, " normalization" of dietary intake of energy, protein, sodium and phosphorus play a crucial role for the renal protection. In more advances stages of CKD, protein-restricted diets are able to prevent or ameliorate uremic symptoms or complications, such as metabolic acidosis, mineral and bone disorders, insulin resistance, proteinuria, hypertension and fluid retention, and to maintain nutritional status [1-3]. Evidence exists that protein-restricted diets can delay the need of dialysis [4], whereas the effect of slowing the rate of GFR decline is not so evident [5].

The severity of protein restriction depends on the level of the residual renal function [6]. Consequently, in the pre-dialysis stages a very low-protein very low-phosphorus diet supplemented with essential amino acids and keto-acids is the preferable option to improve metabolic and nutritional parameters [7].

However, nutritional therapy is not only a matter of dietary protein intake, but it includes also phosphorus and sodium restriction, and adequate energy intake. This is a crucial point since maintenance of a good nutritional status is a pre-requisite and a target of nutritional therapy that allows patients a good quality of life and physical performance. To this aim, energy supply must equal, or even overcome, the energy requirement.

Shifting from conservative to dialysis therapy, increase of protein intake is needed [8]. However, an high protein intake conflicts with the limitation of phosphorus, potassium and salt needed to avoiding the severe complications of hyperkalemia, hyperphosphatemia and excessive interdialytic weight gain [9]. The other side of the nutritional concerns in end-stagerenal-disease (ESRD) patients, is protein energy wasting (PEW) [10]. This quite prevalent condition, especially in elderly dialysis patients, is strictly related to hospitalization, morbidity and mortality $[10,11]$

Even in renal transplanted patients, a correct nutritional approach represents a very important aspects of the clinical care management [12].

Similarly to nutritional education and prescription, physical activity implementation represents a continuum in the natural history of CKD patients (Fig. 1).

\section{Exercise}

It is well known that regular physical exercise is mandatory for the prevention and treatment of obesity, diabetes and insulin resistance which are increasing factors of new onset and of progression of CKD. Body weight lowering strategies should include, as first step, a combination of mild energy reduction and an increase of energy expenditure by aerobic exercise. Unfortunately, this strategy is not always successful [13].

During the course of CKD, physical activity and capacity are largely reduced. Physical inactivity is a long-standing clinical problem among CKD patients especially those undergoing dialysis treatment [14].

The 2011 Cochrane review [15] assessed the effect of regular exercise training in adults with CKD and in kidney transplant recipients on several outcomes, including dietary nutrient intake and parameters of nutritional status. It emerged that physical fitness and physical functioning (defined as the ability and capacity to perform activities of daily living) is severely reduced in adults with CKD and progressively declines from the early stages of CKD to ESRD [15]. Regular exercise training can improve arterial blood pressure control and heart rate, physical fitness walking capacity and several nutritional parameters and quality of life. Positive effects had been found also in elderly CKD patients $[16,17,18]$. 


\section{Kidney \\ Blood Pressure Research}

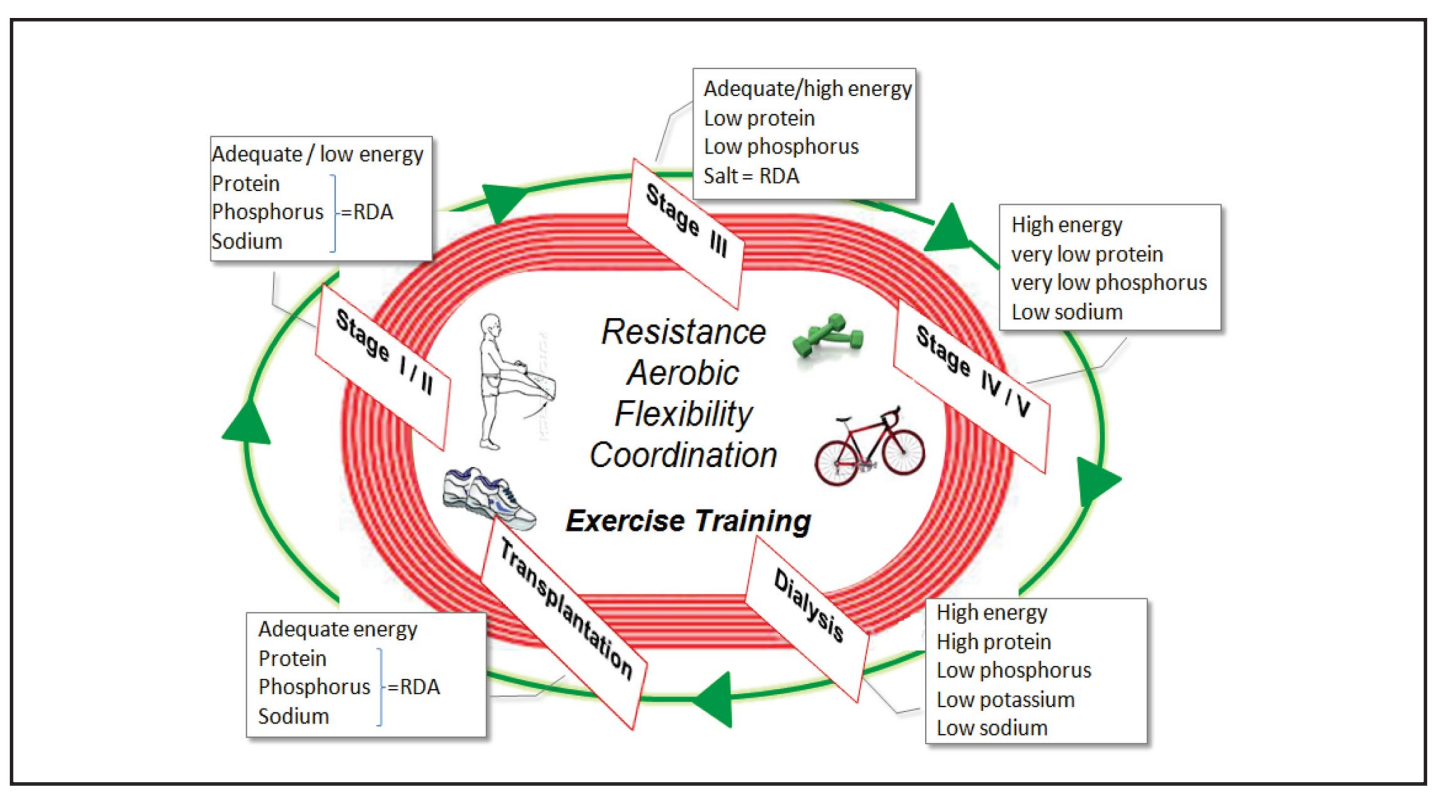

Fig. 1. The "continuum" of exercise implementation and nutritional approach in the CKD patients.

Impaired muscle strength and a decline in physical function is often associated to PEW which depends on the several abnormalities associated to renal failure. The pathogenesis of the so-called "uraemic sarcopenia " is multifactorial including physical inactivity that represents a modifiable and a quite prevalent risk factor. Actually, most of the changes in muscle structure and function seem to be related to deconditioning $[19,20]$.

Data from the literature suggest that CKD patients should be stimulated to increase their physical activity, including coordination and flexibility exercises associated with aerobic and resistance training [21]. Exercise programs may be implemented in the dialysis and/or in the non-dialysis day, depending on the patient's need and willingness as well as on the structural and functional resources [22].

Kouidie et al. evaluated the effects of long-term physical training (4 years) on HD patients' fitness, perception of health and overall life situation [23]. They found that HD patients are able to adhere to long-term physical training programs both on dialysis- and non-dialysis days, with significant increase in exercise capacity especially after the first year. The perception of health was higher in the majority of the patients [23]. The ability of exercise training to alleviate depression and to increase the perception of feeling better improved appetite and contributed to counteract the reduction of energy and protein intake frequently found in HD patients [24].

Sakkas et al. [25] investigated the effect of 6 months of aerobic exercise training on muscle morphology in HD patients and found beneficial effects on muscles with an increment of cross sectional area, reduction of myofiber atrophy and changes in capillarization. They observed that skeletal muscles of uraemic patients responded to exercise stimulus in the same way as the normal population [25].

A correct nutritional approach and regular physical activity also represent very important aspects of the clinical care management in renal transplanted patients [26]. Poor functional capacity predicts a poor outcome for older patients undergoing renal transplantation [27].

Weight gain after kidney transplantation is a significant risk factor for diminished long-term outcomes which affects up to $90 \%$ of kidney transplant recipients; changes in dietary intake and lack of physical activity are strong factors causing weight gain following kidney transplantation [26]. Gain in adiposity after renal transplantation is related to high consumption of mono- and disaccharides, energy-rich drinks, and low daily physical activity [28]. 


\section{Kidney Blood Pressure Research}

Despite a number of benefits, the effect of increased physical activity on long-term survival of HD patients are still lacking [23].

\section{Exercise training and low protein diet in CKD}

Proper nutrition and regular physical activity are relevant aspect at any stage of a renal patient's history (Fig.1). Although evidence exits about the positive clinical effects of lowprotein regimens in CKD, the fear that a protein restriction could cause protein malnutrition and muscle wasting still remains. This could happen only if the energy intake is not adequate, or the essential aminoacids intake is not sufficient or when metabolic acidosis is not corrected. Basically, reduction of protein intake reduces protein synthesis but also reduces protein catabolism, so nitrogen balance is maintained in equilibrium. However, when protein and energy intakes are inadequately low, net protein catabolism occurs.

The effect of resistance training during low-protein regimens counteract the tendency to impaired muscle cell metabolism. Castaneda et al. [29] studied 26 CKD patients following a low-protein $(0.6 \mathrm{~g} / \mathrm{Kg} \mathrm{b.w})$ diet. They found an increase in type I and II fiber cross-sectional areas, an improvement of leucine oxidation, serum albumin levels and muscle strength and a reduction of inflammation in patients who performed resistance training, when compared to patients not undergoing resistance training. They concluded that resistance training seems to be effective and protective even in CKD patients on a low-protein diet, by improving protein utilization, muscle mass and function, and body composition $[29,30]$.

Although different from normal controls, no difference in muscle metabolism and function was observed in patients on a very low protein diet $(0.3 \mathrm{~g} / \mathrm{Kg} / \mathrm{d})$ supplemented with essential aminoacids and ketoacids when compared to patients on standard lowprotein $(0.6 \mathrm{~g} / \mathrm{kg} / \mathrm{d}) \operatorname{diet}[31]$.

It is crucial to underline that exercise activity is a matter of energy supply rather than protein intake. In order to satisfy the increased energy requirement, it is mandatory that the recommendation of increasing exercise and physical activities are also accompanied by the recommendation to increase energy intake. In the CKD patients on low protein regimens, the energy needs can be obtained by increasing the intake of protein-free foods which provide carbohydrates and are almost free of protein, phosphorus, potassium or sodium [32]. These protein-free products represent a real "green power fuel" for CKD patients.

\section{Exercise training and Nutrition in ESRD}

Concerning the influence of progressive resistance training on markers of nutritional status, positive effects have been reported in the PEAK (Progressive Exercise for Anabolism in Kidney Disease) study. HD patients undergoing 12 weeks of high intensity progressive resistance training administered during dialysis treatment have reported an increase in insulin sensitivity, a reduction of intramuscular lipids, a statistically significant increase in total strength, body weight and BMI, mid-thigh and mid-arm circumference [33]. Frey et al. did not find any differences in pre-albumin levels while pre-dialysis and post dialysis albumin levels tend to slightly increase over time in ESRD patients who took part to an aerobic exercise program performed during dialysis treatment [24].

Regular exercise training (regardless of type, intensity, length of intervention, or supervision) was associated with a significant increase in energy intake. Instead, no significantly increase of protein intake was reported in patients performing cardiovascular and/or resistance exercise training [14]. Our experience confirm these findings: in a in a cohort of hemodialysis patients, the level and intensity of spontaneous physical activity was positively related to the daily energy intake energy [34].

Evidences exist that exercise is an effective anabolic strategy in particular when it is performed close to the administration of nutritional supports both in healthy and CKD subjects. Exercise increases insulin sensitivity and responsiveness [35]: insulin-stimulated glucose and amino acids transport increased following muscle contraction even at a constant receptors and nutrient concentrations [36]. It is known that supplementation of carbohydrate in the early post-exercise stimulate a more rapid glycogen storage. A similar 


\section{Kidney Blood Pressure Research}

mechanism has been proposed for protein supplementation (probably insulin-mediated) resulting in muscle hypertrophy and increase in muscle strength. Hence, a close relationship exists among exercise, nutritional status and nutrients intakes, with particular attention to the timing of the nutrients administration [37-39].

Both in healthy and CKD subjects, short-term studies showed that the combination of exercise training and oral supplementation increases muscle protein content more than exercise or nutritional supplementation alone. There is also evidence that intra-dialysis exercise, combined with oral or parenteral nutrition, enhances amino acid uptake and protein content in the muscle tissue of HD patients. Pupim et al [40] studied two groups of HD patients: one only with intra dialytic parenteral nutrition (IDPN) and the other with IDPN plus exercise. Patients were studied before, during, and $2 \mathrm{~h}$ after an HD session by use of a infusion of L- $\left[1-{ }^{13} \mathrm{C}\right]$ leucine and L-[ring- $\left.{ }^{2} \mathrm{H}_{5}\right]$ phenylalanine. During HD, exercise combined with IDPN promoted two-fold increment in forearm muscle essential amino acid uptake and muscle protein when compared with IDPN alone. Whole body protein homeostasis and energy expenditure were not altered by exercise treatment [40].

These results are in accordance with those of Majchrzak et al [41] who found enhanced anabolic effects of oral intradialytic nutritional supplementation on skeletal muscle protein turnover after a single bout of resistance training. Similar findings have been reported by Dong J et al. [42] who tested the effect of a long-term resistance training combined with intradialytic oral supplementation in HD patients. The Authors found a statistically significant increase in body weight that can be considered as a positive result. In fact evidence exists that increasing body weight in HD patients improves their survival [42]. In a small cohort of HD patients, 16 weeks of strength training was performed together with the administration of protein or a no protein drink after every training session. After the training, improvements in muscle strength and power, physical performance, and quality of life occurred. However, no additional benefit was observed by combining the training and protein supplementation. [43].

A randomized clinical trial is in progress for analyzing the impact of intra-dialysis progressive exercise training and adequate nutritional supplementation on markers of PEW, functional capacities and quality of life of adult patients in hemodialysis [44].

\section{Conclusion}

In summary, regular physical activity can positively affect the nutritional status and the perception of well-being of CKD patients and may facilitate the anabolic effects of nutritional interventions. Exercise training, coupled with adequate nutritional support is a therapeutic intervention able to prevent the loss of lean body mass in CKD patients. In addition, improving of quality of life is generally recorded. These strategies need to be implemented and represent a promising field of investigations in all the stages of CKD.

\section{Disclosure Statement}

The authors of this work declare that they do not have any conflict of interests.

\section{References}

1 Mitch WE, Remuzzi G: Diets for patients with chronic kidney disease, still worth prescribing. J Am Soc Nephrol 2004;15:234-237.

-2 Fouque D, Aparicio M: Eleven reasons to control the protein intake of patients with chronic kidney disease. Nature Clin Pract 2007;3:383-392. 


\section{Kidney \\ Blood Pressure Research}

3 Cupisti A, D’Alessandro C, Morelli E, Rizza GM, Galetta F, Franzoni F, Barsotti G: Nutritional status and dietary manipulation in predialysis chronic renal failure patients. J Ren Nutr 2004;14:127-133.

4 Fouque D, Wamg P, Laville M, Boissel JP: Low protein diets delay end-stage renal disease in non diabetic adults with chronic renal failure. Nephrol Dial Transplant 2000;15:1986-1992.

5 Kasiske BL, Lakatua JD, Ma JZ, Louis TA: A meta-analysis of the effects of dietary protein restriction on the rate of decline in renal function Am J Kidney Dis 1998;31:954-961.

-6 Aparicio M, Cano NJ, Cupisti A, Ecder T, Fouque D, Garneata L, Liou HH, Lin S, Schober-Halstenberg HJ, Teplan V, Zakar G: Keto-acid therapy in predialysis chronic kidney disease patients: consensus statements. J Ren Nutr 2009;19:S33-S35.

7 Aparicio M, Bellizzi V, Chauveau P, Cupisti A, Ecder T, Fouque D, Garneata L, Lin S, Mitch W, Teplan V, Yu X, Zakar G: Do Ketoanalogues Still Have a Role in Delaying Dialysis Initiation in CKD Predialysis Patients? Semin Dial 2013;26:714-719.

-8 Fouque D, Vennegoor M, Ter Wee P, Wanner C, Basci A, Canaud B, Haage P, Konner K, Kooman J, MartinMalo A, Pedrini L, Pizzarelli F, Tattersall J, Tordoir J, Vanholder R: EBPG Guideline on Nutrition. Nephrol Dial Transplant 2007;22:ii45-ii87.

- Laville M, Fouque D: Nutritional aspects in hemodialysis. Kidney Int Suppl 2000;76:S133-139.

10 Fouque D, Kalantar-Zadeh K, Kopple J, Cano N, Chauveau P, Cuppari L, Franch H, Guarnieri G, Ikizler TA, Kaysen G, Lindholm B, Massy Z, Mitch W, Pineda E, Stenvinkel P, Treviño-Becerra A, Wanner C: A proposed nomenclature and diagnostic criteria for protein- energy wasting in acute and chronic kidney disease. Kidney Int 2008;73:391-398.

11 Ikizler TA, Cano NJ, Franch H, Fouque D, Himmelfarb J, Kalantar-Zadeh K, Kuhlmann MK, Stenvinkel P, TerWee P, Teta D, Wang AY, Wanner C: Prevention and treatment of protein energy wasting in chronic kidney disease patients: a consensus statement by the International Society of Renal Nutrition and Metabolism. Kidney Int 2013;84:1096-1107.

12 Chan M, Patwardhan A, Ryan C, Trevillian P, Chadban S, Westgarth F, Fry K; Caring for Australasians with Renal Impairment; Dietitians Association of Australia: Evidence-based guidelines for the nutritional management of adult kidney transplant recipients. J Ren Nutr 2011;21:47-51.

13 Baria F, Kamimura MA, Aoike DT, Ammirati A, Rocha ML, de Mello MT, Cuppari L: Randomized controlled trial to evaluate the impact of aerobic exercise on visceral fat in overweight chronic kidney disease patients. Nephrol Dial Transplant 2014;29:857-864.

14 Clyne N, Jogestrand T, Lins L, Pehrsson S, Ekelund L: Factors limiting physical working capacity in predialytic uraemic patients. Acta Med Scand 1987;222:183-190.

15 Heiwe S, Jacobson SH: Exercise training for adults with chronic kidney disease. Cochrane Database Syst Rev 2011;10:CD003236.

16 Fitts SS, Guthrie MR, Blagg CR: Exercise coaching and rehabilitation counseling improve quality of life for predialysis and dialysis patients. Nephron 1999;82:115-121.

17 Painter P, Carlson L, Carey S, Paul SM, Myll J: Physical functioning and health-related quality-of-life changes with exercise training in hemodialysis patients. Am J Kidney Dis 2000;35:482-492.

18 Heiwe S, Tollbäck A, Clyne N: Twelve weeks of exercise training increases muscle function and walking capacity in elderly pre-dialysis patients and healthy subjects. Nephron 2001;88:48-56.

19 Fahal IH: Uraemic sarcopenia: aetiology and implications. Nephrol Dial Transplant 2013, DOI 10.1093/ ndt/gft070.

20 Workeneh BT, Mitch WE: Review of muscle wasting associated with chronic kidney disease. Am J Clin Nutr 2010;91:1128S-1132S.

21 Johansen KL, Chertow GM, Ng AV, Mulligan K, Carey S, Schoenfeld PY, Kent-Braun JA: Physical activity levels in patients on hemodialysis and healthy sedentary controls. Kidney Int 2000;57:2564-2570.

-22 Kouidi E, Grekas D, Deligiannis A, Tourkantonis A: Outcomes of long-term exercise training in dialysis patients: comparison of two training programs. Clin Nephr 2004;61:s31-s38.

-23 Cupisti A, D'Alessandro C, Bottai A, Fumagalli G, Capitanini A: Physical activity and exercise training: a relevant aspect of the dialysis patient's care. Intern Emerg Med 2013;8:31-34.

24 Frey S, Mir AR, Lucas M: Visceral protein status and caloric intake in exercising versus non-exercising individuals with end-stage renal disease. J Ren Nutr 1999;9:71-77.

25 Sakkas GK, Sargeant AJ, Mercer TH, Ball D, Koufaki P, Karatzaferi C, Naish PF: Changes in muscle morphology in dialysis patients after 6 months of aerobic exercise training. Nephrol Dial Transplant 2003;18:1854-1861. 


\section{Kidney \\ Blood Pressure Research}

26 Cupples CK, Cashion AK, Cowan PA, Tutor RS, Wicks MN, Williams R, Eason JD: Characterizing dietary intake and physical activity affecting weight gain in kidney transplant recipients. Prog Transplant 2012;22:62-70.

27 Yango AF, Gohh RY, Monaco AP, Reinert SE, Gautam A, Dworkin LD, Morrissey PE: Excess risk of renal allograft loss and early mortality among elderly recipients is associated with poor exercise capacity. Clin Nephrol 2006;65:401-407.

-28 Zelle DM, Kok T, Dontje ML, Danchell EI, Navis G, van Son WJ, Bakker SJ, Corpeleijn E: The role of diet and physical activity in post-transplant weight gain after renal Transplantation. Clin Transplant 2013:27:E484-E490.

29 Castaneda C, Gordon PL, Uhlin KL, Levey AS, Kehayias JJ, Dwyer JT, Fielding RA, Roubenoff R, Singh MF: Resistance training to counteract the catabolism of a low protein diet in chronic renal insufficiency: A randomized, controlled trial. Ann Intern Med 2001;135:965-976.

30 Castaneda C, Gordon PL, Parker RC, Uhlin KL, Roubenoff R, Levey AS: Resistance training to reduce the malnutrition-inflammation complex syndrome of chronic kidney disease. Am J Kidney Dis 2004;43:607616.

-31 Cupisti A, Licitra R, Chisari C, Stampacchia G, D’Alessandro C, Galetta F, Rossi B, Barsotti G: Skeletal muscle and nutritional status in chronic renal failure on a protein restricted diet. J Int Med 2004;255:115-124.

32 D’Alessandro C, Rossi A, Innocenti M, Ricchiuti G, Bozzoli L, Sbragia G, Meola M, Cupisti A: Dietary Protein Restriction for Renal Patients: Don't Forget Protein-Free Foods. J Ren Nutr 2013;23:367-371.

-33 Cheema B, Abas H, Smith B, O'Sullivan A, Chan M, Patwardhan A, Kelly J, Gillin A, Pang G, Lloyd B, Singh MF: Progressive exercise for anabolism in kidney disease (PEAK): a randomized, controlled trial of resistance training during hemodialysis. J Am Soc Nephrol 2007;18:1594-1601.

-34 Cupisti A, Capitanini A, Betti G, D'Alessandro C, Barsotti G: Assessment of habitual physical activity and energy expenditure in dialysis patients and relationships to nutritional parameters. Clin Nephrol 2011;75:218-225.

-35 Wasserman DH, Geer RJ, Rice DE, Bracy D, Flakoll PJ, Brown LL, Hill JO, Abumrad NN: Interaction of exercise and insulin action in humans. Am J Physiol Endocrinol Metab 1991;260:E37-E45.

-36 Zorzano A, Balon TW, Garetto LP, Goodman MN, Ruderman NB: Muscle $\alpha$-aminoisobutyric acid transport after exercise: enhance stimulation by insulin. Am J Physiol Endocrinol Metab 1985;248:E546-E552.

37 Andersen LL, Tufekovic G, Zebis MK, Crameri RM, Verlaan G, Kjaer M, Suetta C, Magnusson P, Aagaard P: The effect of resistance training combined with timed ingestion of protein on muscle fiber size and muscle strength. Metabolism 2005;54:151-156.

-38 Esmarck B, Andersen JL, Olsen S, Richter EA, Mizuno M, Kjaer M: Timing of post-exercise protein intake is important for muscle hypertrophy with resistance training in elderly humans. J Physiol 2001;535:301-311.

-39 Levenhagen DK, Gresham JD, Carlson MG, Maron DJ, Borel MJ, Flakoll PJ: Post-exercise nutrient intake timing in humans is critical to recovery of leg glucose and protein homeostasis. Am J Physiol Endocrinol Metab 2001;280:E982-E993.

40 Pupim LB, Flakoll PJ, Levenhagen DK, Ikizler TA: Exercise augments the acute anabolic effects of intradialytic parenteral nutrition in chronic hemodialysis patients. Am J Physiol Endocrinol Metab 2004;286:E589-E597.

41 Majchrzak KM, Pupim LB, Flakoll PJ, Ikizler TA: Resistance exercise augments the acute anabolic effects of intradialytic oral nutritional supplementation. Nephrol Dial Transplant 2008;23:1362-1369.

-42 Dong J, Sundell MB, Pupim LB, Wu P, Shintani A, Ikizler TA: The effect of resistance exercise to augment long-term benefits of intradialytic oral nutritional supplementation in chronic hemodialysis patients. J Ren Nutr 2011;21:149-159.

43 Molsted S, Harrison AP, Eidemak I, Andersen JL: The Effects of High-Load Strength Training With Proteinor Nonprotein-Containing Nutritional Supplementation in Patients Undergoing Dialysis. J Ren Nutr 2013;23:132-140.

44 Magnard J, Deschamps T, Cornu C, Paris A, Hristea D: Effects of a six-month intradialytic physical ACTIvity program and adequate NUTritional support on protein-energy wasting, physical functioning and quality of life in chronic hemodialysis patients: ACTINUT study protocol for a randomized controlled trial. BMC Nephrology 2013;14:259. 